\title{
Simple two spectrophotometric methods for estimation of Cephalexin in pure and pharmaceutical dosage form
}

\section{Neda Ibrahim Mahdi}

Department of Chemistry, College of Science, Al-Mustansiriyah, University, Baghdad, Iraq (nadamahde@uomustansiriyah.edu.iq)

\section{Article Information}

Received: 17/09/2020

Accepted: 04/01/2021

\section{Keywords:}

Cephalexin, Area under curve, spectrophotometric, pharmaceutical dosage form, SDI-Iraq

\begin{abstract}
This study describes two extraction-free and direct spectrophotometric methods for the determination of Cephalexin in a pure and pharmaceutical dosage form. In this study, a zero-order method has exhibited maximum absorption max at $263 \mathrm{~nm}$, while area under curve method has calculated in the range $260-266 \mathrm{~nm}$. The Linearity of both methods in the range (10- $60 \mathrm{~nm}$ ), the limit of detection (LOD) is 0.808 for Zero-order method and 0.781 for the area under curve method. These methods are successfully applied to determination of Cephalexin in a pharmaceutical dosage form.
\end{abstract}

\section{Introduction:}

Cephalexin is a kind of antibiotics has been used to infections of skin and organs by kill bacteria in both human and animals [1, 2]. Many analytical methods in the literature have been suggested for estimation of cephalexin in serum, meat and pharmaceutical dosage form. Most of these methods are depended on temperature control, lead to increased environmental pollution, took a long time for operation and expensive, these methods include HPLC-mass in plasma of swine [3], RP-UFLC in pharmaceutical forms [4], electrochemical immunosensor in meat samples [5], fluorescence probes [6], used three methods spectrophotometric, voltammetric and titration by means of potassium carbonate as analytical reagent[7], flame atomic emission[8], First and second derivative spectrophotometric [9], electrochemical sensors in serum [10] and RP-HPLC [11].

In this study, developed a fast, simple, inexpensive and free of environmental effects methods included spectrophotometric methods namely: zero-order and area under curve used for determination of Cephalexin in pure and marketed capsule formulations. 


\section{Experimental}

\section{Instruments}

Shimadzu spectrophotometer model (1800) was used for the spectrum and absorbance measurements using quartz cells.

2. Solutions: 0.1 gm of pure cephalexin $\left(\mathrm{C}_{16} \mathrm{H}_{17} \mathrm{~N}_{3} \mathrm{O}_{4} \mathrm{~S}\right.$, M.wt $=347.4 \mathrm{~g} / \mathrm{mol}$, SDI - iraq $)$ was dissolved in ethanol and completed the volume to $100 \mathrm{ml}$ with ethanol to obtain $1000 \mathrm{mg} /$ L.

3. Preparation of calibration the curves: six different volumes were taken from stock standard solution $1000 \mathrm{mg} / \mathrm{L}$ are: $(0.5,1,1.5,2,2.5$ and $3 \mathrm{ml})$, these volumes transferred to set of $50 \mathrm{ml}$ volumetric flasks and diluted with ethanol to an obtained concentration of pure cephalexin equal to $(10,20,30,40,50$ and $60 \mathrm{mg} / \mathrm{L})$.

4. Assay of market Cephalexin capsules: 10 capsules of Cephalexin were weighed. Taken $0.1 \mathrm{gm}$ of this powder and dissolved with ethanol, this solution is transferred into a $100 \mathrm{ml}$ volumetric flask to give the concentration of $1000 \mathrm{mg} / \mathrm{L}$. A set of appropriate dilution was made in $50 \mathrm{ml}$ volumetric flask with ethanol and the concentrations of Cephalexin were determined.

\section{Results and discussion}

\section{1-Zero order method}

Zero order spectra were recorded a single peak at the wavelength of $263 \mathrm{~nm}$ for pure Cephalexin (Fig.1); Beer-Lambert's law was applying in the range 10-60 mg/l and the linearity data for this method is presented in Table 1.

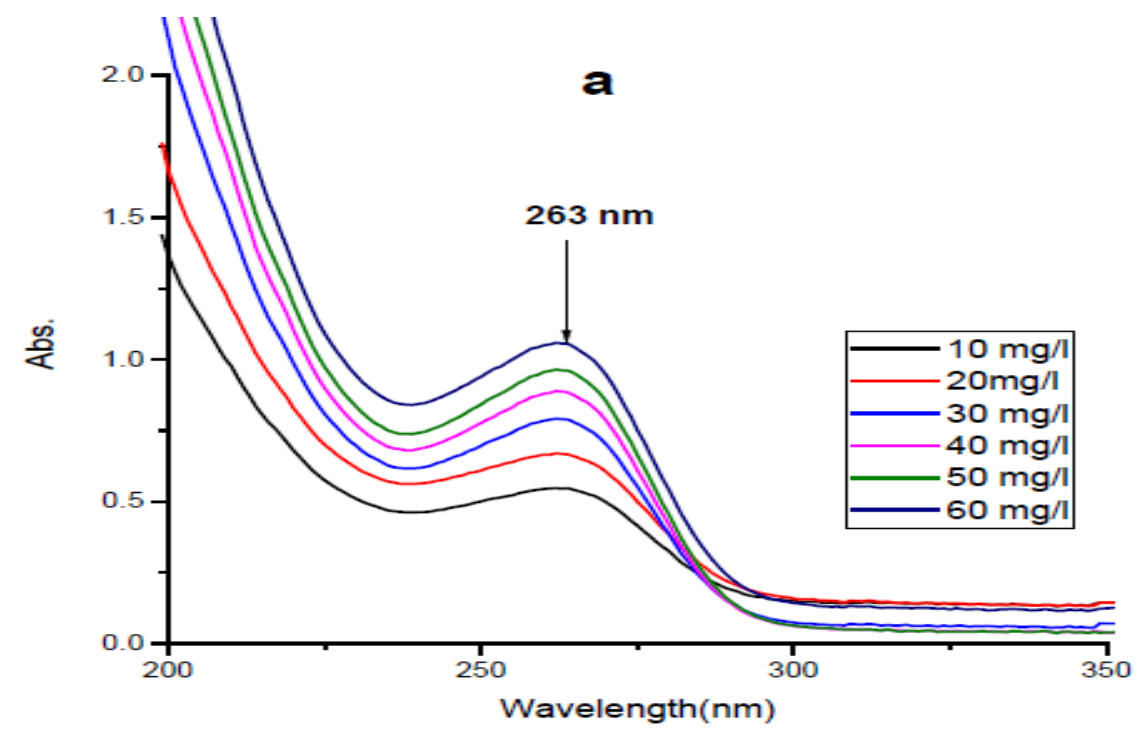




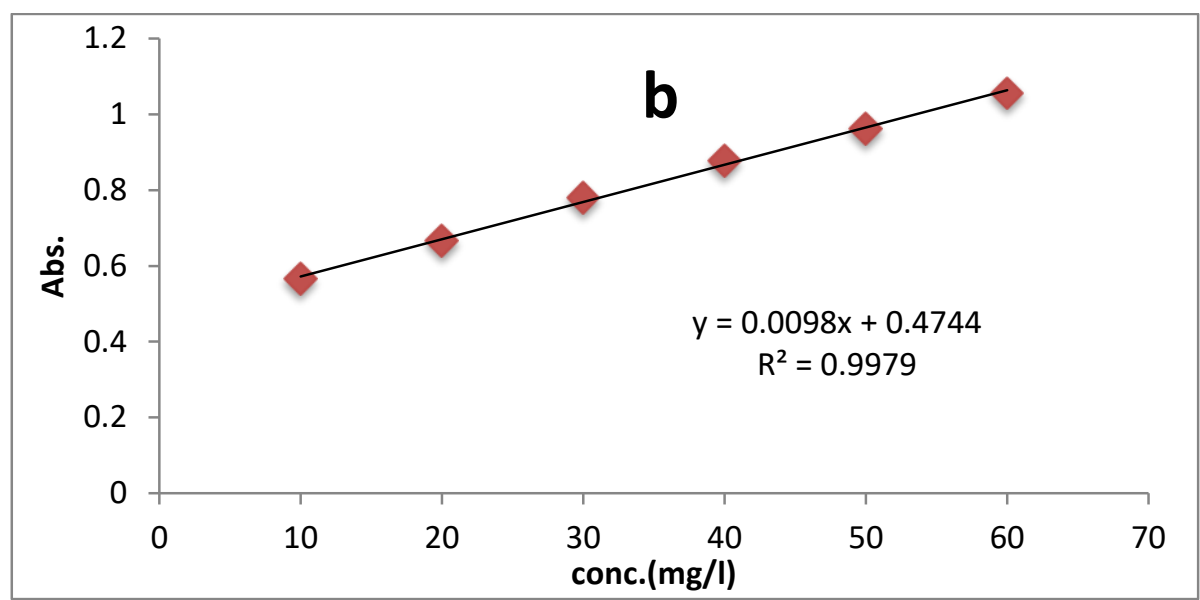

Fig. 1: (a) Zero-order spectra of Cephalexin 10-60 $\mathrm{mg} / \mathrm{l}$ at peak $=263 \mathrm{~nm}$ and (b) the calibration curve taken of Cephalexin for this method.

\section{2- Area under curve method}

Area under curve for Cephalexin standard solutions was calculated in the range of 260$266 \mathrm{~nm}$ (Figure 2), the principle of work Area under curve is depended on the following equation $[12,13]$ :

$\mathrm{AUC}=\frac{\lambda 1}{\lambda 2} \mathrm{Ad} \lambda=0.061 \mathrm{x}+2.7418\left(\mathrm{R}^{2} 0.9976\right)$

Where, $\lambda 1$ is a starting wavelength of $260 \mathrm{~nm}, \lambda 2$ is the endpoint wavelength of $266 \mathrm{~nm}$; A is absorbance of Cephalexin standard solutions, $\mathrm{d} \lambda$ is the area under curve between two selected wavelengths, $\mathrm{x}$ is the concentration of Cephalexin standard solutions and $\mathrm{R}^{2}$ is a determination coefficient.

The linearity between 10- $60 \mathrm{mg} / \mathrm{L}$ of Cephalexin standard solutions and other validation parameters are shown in table1 and figure3. Table1 has shown the values of statistical parameters of two methods. 

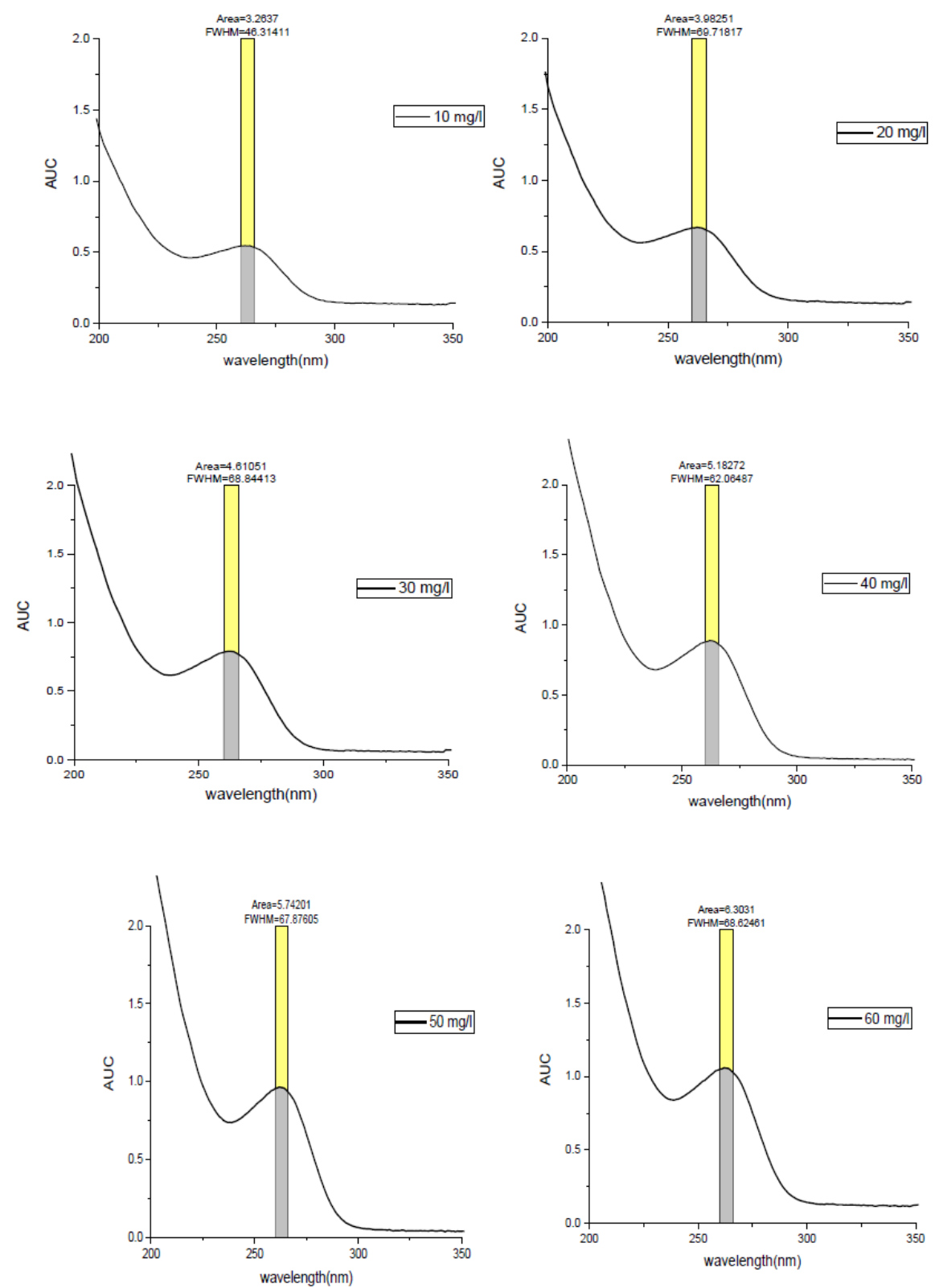

Fig. 2: Area under curves of Cephalexin with the concentrations of $10-60 \mathrm{mg} / \mathrm{L}$ and at the wavelength range (260-266nm)

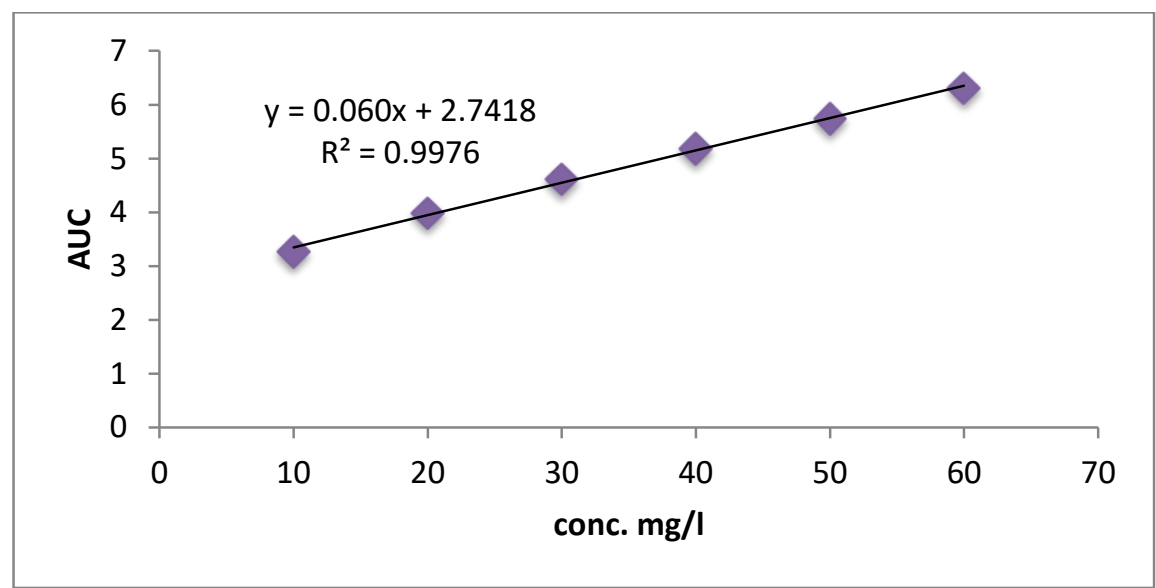

Fig. 3: Area under curve method-calibration curve for Cephalexin 10-60 mg/L at area (260266nm). 
Table 1: Statistical parameters obtained from the calibration curves of both methods.

\begin{tabular}{ccc}
\hline method & Zero-order & Area under curve \\
\hline Wavelength nm & $263 \mathrm{~nm}$ & $260-266 \mathrm{~nm}$ \\
\hline $\mathrm{R}^{2}$ & 0.9979 & 0.9976 \\
\hline $\begin{array}{c}\text { Linearity } \\
\text { range(mg/L) }\end{array}$ & $10-60$ & $10-60$ \\
\hline Equation for linearity & $\mathrm{y}=0.0098 \mathrm{x}+0.4744$ & $\mathrm{Y}=0.060 \mathrm{x}+2.7418$ \\
\hline Slope & 0.0098 & 0.060 \\
\hline Intercept & 0.4744 & 2.7418 \\
\hline SD of intercept & 0.022 & 0.142 \\
\hline Mean* \pm SD & $108.327 \pm 4.140$ & $101.265 \pm 5.075$ \\
\hline LOD (mg/L) & 0.808 & 0.781 \\
\hline
\end{tabular}

* mean of recovery, LOD $=$ limit of detection $=3.3 \times \mathrm{SD} / \mathrm{S}$ and SD is the standard deviation of the intercept

\section{Accuracy and Precision}

Percentage of relative error (E\%) and Recovery (Rec\%) were used to check the accuracy and precision of this study. two concentrations were taken 20 and $40 \mathrm{mg} / \mathrm{L}$ of Cephalexin standard solutions. Each concentration was scanned three times. The accuracy and precision data were summarized in table2.

Table 2: Relative error and Recovery of two methods.

\begin{tabular}{|c|c|c|c|c|c|}
\hline \multirow[t]{2}{*}{ Methods } & \multicolumn{2}{|c|}{$\begin{array}{c}\text { Concentration of } \\
\text { Cephalexin }(\mathrm{mg} / \mathrm{L})\end{array}$} & \multirow{2}{*}{$\begin{array}{c}\text { Relative } \\
\text { error } \\
\left(\mathrm{Er}^{*} \%\right)\end{array}$} & \multirow{2}{*}{$\begin{array}{l}\text { Recovery } \\
\left(\operatorname{Rec}^{*} \%\right)\end{array}$} & \multirow[t]{2}{*}{ RSD*\% } \\
\hline & Taken & found & & & \\
\hline \multirow{2}{*}{ Zero-order } & 20 & 19.77 & -1.15 & 98.85 & 0.189 \\
\hline & 40 & 39 & -2.50 & 97.50 & 0.578 \\
\hline \multirow{2}{*}{$\begin{array}{l}\text { Area under } \\
\text { curve }\end{array}$} & 20 & 20.68 & -3.4 & 103.40 & 0.907 \\
\hline & 40 & 38.83 & -2.925 & 97.075 & 1.069 \\
\hline
\end{tabular}

$*$ Average of three time, $\mathrm{Er} \%=\frac{\text { found-taken }}{\text { taken }} \times 100, \mathrm{Rec} \%=\mathrm{E} \%+100, \mathrm{RSD} \%=$ relative standard deviation

\section{Application}

Cephalexin 500 Capsules (Each capsule contains Cephalexin monohydrate $500 \mathrm{mg}$ ) were determined by using two suggested methods. Two concentrations 25 and $55 \mathrm{mg} / \mathrm{L}$ of market Cephalexin capsule were measured three times by using UV-Visible spectrophotometer. Figures 4 and 5 of the market Cephalexin capsule shows there were no differences between them and the Cephalexin standard curves (Figures 1 and 2), it means that two proposed methods are suitable for the determination of Cephalexin in pure and capsule formulation. The percentage of relative error and recoveries are listed in table3. 


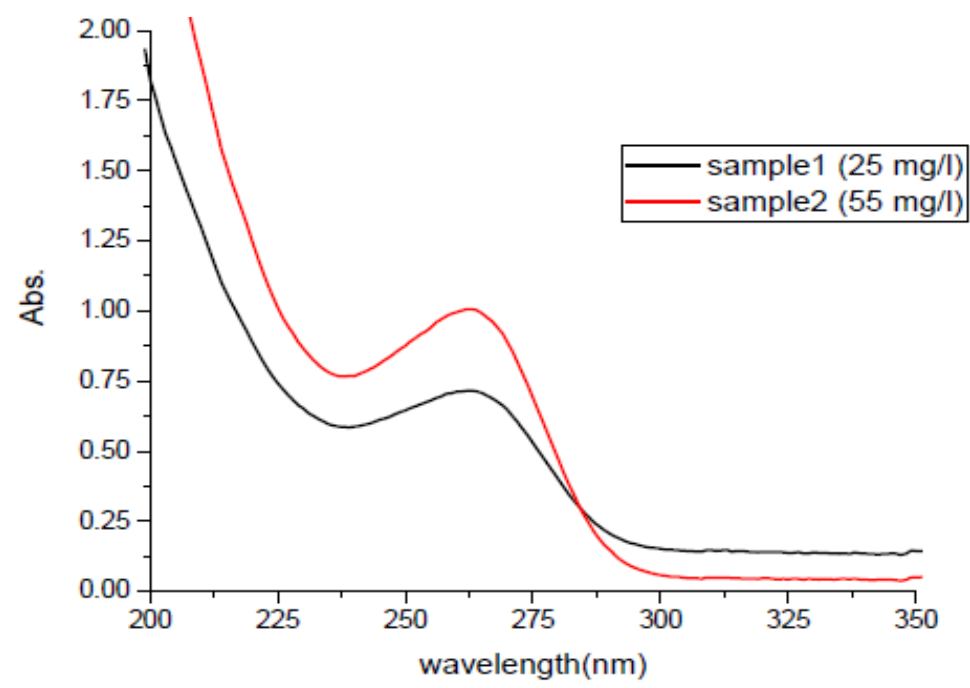

Fig. 4: Zero-order method-spectrum of market Cephalexin capsule at 25 and $55 \mathrm{mg} / \mathrm{L}$
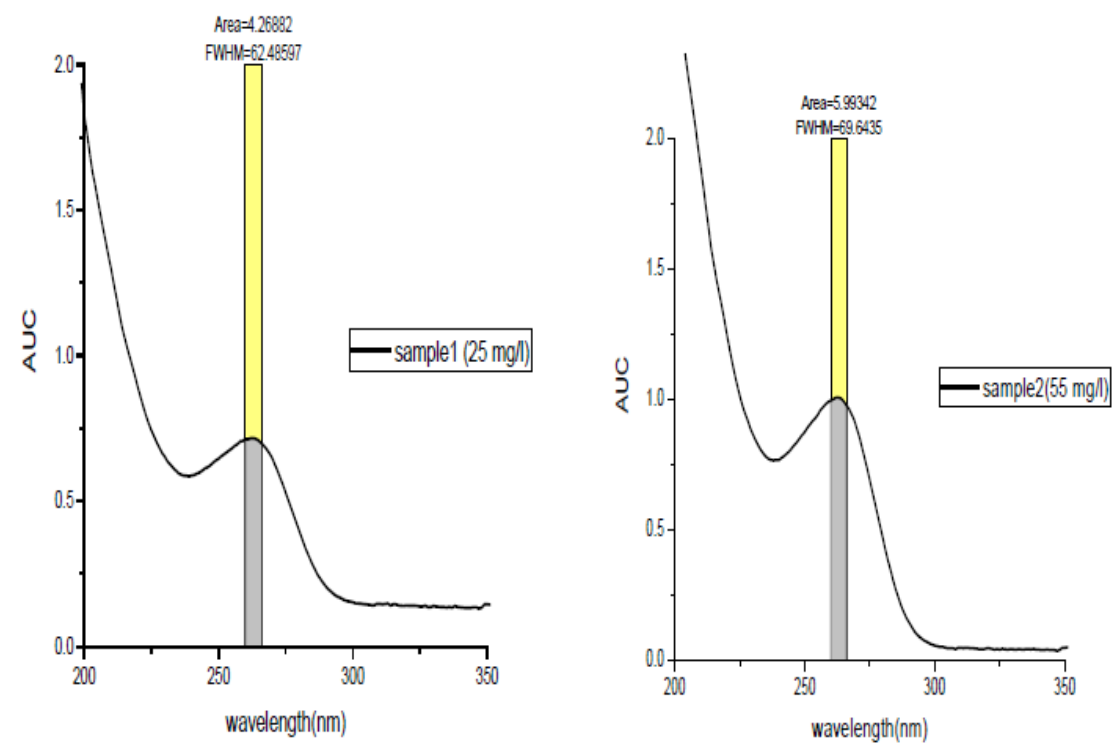

Fig. 5: Area under curve method-spectrum of market Cephalexin capsule at 25 and $55 \mathrm{mg} / \mathrm{L}$

Table 3: The relative error and recovery of the market Cephalexin capsule at 25 and $55 \mathrm{mg} / \mathrm{L}$

\begin{tabular}{|c|c|c|c|c|c|c|}
\hline \multirow[t]{2}{*}{$\begin{array}{l}\text { Pharmaceutical } \\
\text { market tablet }\end{array}$} & \multirow[t]{2}{*}{ method } & \multicolumn{2}{|c|}{$\begin{array}{c}\text { Conc. of } \\
\text { Cephalexin } \\
\text { capsule mg/L }\end{array}$} & \multirow[t]{2}{*}{$\mathrm{E}^{*} \%$} & \multirow[t]{2}{*}{ Rec.*\% } & \multirow[t]{2}{*}{$\mathrm{RSD}^{*} \%$} \\
\hline & & taken & found & & & \\
\hline \multirow{4}{*}{$\begin{array}{c}\text { Cephalexin } 500 \\
\text { Capsules-SDI }\end{array}$} & Zero- & 25 & 24.66 & -1.36 & 106.640 & 0.793 \\
\hline & order & 55 & 56.11 & +2.01 & 102.01 & 0.665 \\
\hline & $\begin{array}{l}\text { Area } \\
\text { under }\end{array}$ & 25 & 25.28 & +1.12 & 101.12 & 0.873 \\
\hline & cait & 55 & 56.86 & +3.381 & 103.381 & 0.702 \\
\hline
\end{tabular}

*Average of three time, SDI= the state Company for Drugs Industry and Medical Appliances Samarra Iraq 


\section{Comparison with previous studies}

A comparison of two analytical parameters of present methods (linearity range and LOD) with previous studies for determination of Cephalexin in different samples by using different methods are presented in table 4.

Table 4: Comparison with previous studies.

\begin{tabular}{ccccc}
\hline Method & Range & LOD & Samples & Ref. \\
\hline RP-UFLC & $1-120$ & 0.24 & Pharmaceutical & 4 \\
& $\mu \mathrm{g} / \mathrm{ml}$ & $\mu \mathrm{g} / \mathrm{ml}$ & dosage form & \\
Electrochemical & $1-800$ & 45.7 & Meat samples & 5 \\
immunosensor & $\mathrm{ng} / \mathrm{ml}$ & $\mathrm{ng} / \mathrm{ml}$ & & \\
Fluorescence probes & $0.1-50$ & 0.06 & Milk samples & 6 \\
Kinetic- & $\mu \mathrm{g} / \mathrm{L}$ & $\mu \mathrm{g} / \mathrm{L}$ & & \\
spectrophotometric & $\mu \mathrm{gg} / \mathrm{mL}$ & $\mu \mathrm{g} / \mathrm{mL}$ & Drug samples & 7 \\
Colorimetric & $5-40 \mu \mathrm{g} /$ & 2.814 & Pharmaceutical & 8 \\
spectrophotometric & $\mathrm{mL}$ & $\mu \mathrm{g} / \mathrm{mL}$ & preparations & 8 \\
Zero-order & $10-60$ & 0.808 & Capsules & $\begin{array}{c}\text { Present } \\
\text { study } \\
\text { spectrophotometric }\end{array}$ \\
AUC & $\mathrm{mg} / \mathrm{L}$ & $\mathrm{mg} / \mathrm{L}$ & & $\begin{array}{c}\text { Present } \\
\text { study }\end{array}$ \\
spectrophotometric & $\mathrm{mg} / \mathrm{L}$ & $\mathrm{mg} / \mathrm{L}$ & Capsules & \\
\hline
\end{tabular}

\section{Conclusion}

A fast, simple and cheap two spectrophotometric methods were used for estimation of cephalexin. Two methods had a high level of sensitivity for the detection of cephalexin in the range 10-60 mg/L. This study showed it can be determination of cephalexin at the absence of extraction, $\mathrm{pH}$ control and color development steps, which mean these methods, were suitable for estimation of cephalexin in pure and market capsule.

\section{Acknowledgement}

The author is many gratified to the Chemistry Dept., College of Science, Al-Mustansiriyah University for helping to do this work.

\section{References}

1. Khosravi, R., Zarei, A., Heidari, M., Ahmadfazeli, A., Vosughi, M., \& Fazlzadeh, M. (2018). Application of $\mathrm{ZnO}$ and $\mathrm{TiO}_{2}$ nanoparticles coated onto montmorillonite in the presence of $\mathrm{H}_{2} \mathrm{O}_{2}$ for efficient removal of cephalexin from aqueous solutions. Korean Journal of Chemical Engineering, 35(4), 1000-1008.

2. Li, N., Tian, Y., Zhao, J., Zhang, J., Zuo, W., Kong, L., \& Cui, H. (2018). Z-scheme 2D/3D g-C3N4@ ZnO with enhanced photocatalytic activity for cephalexin oxidation under solar light. Chemical Engineering Journal, 352, 412-422.

3. Wang, L., Li, X., Wang, Y., Wang, C., Ye, D., Zhou, L. and Xia, X. (2019). Determination of cephalexin residual level using ultra-high-performance liquid chromatography-tandem 
mass spectrometry: Residue depletion study in swine. Journal of Chromatography B, 1124, 233-238.

4. Panda, S. S., KUMAR, B. V., Dash, R., \& Mohanta, G. (2013). Determination of cephalexin monohydrate in pharmaceutical dosage form by stability-indicating RP-UFLC and UV spectroscopic methods. Scientia Pharmaceutica, 81(4), 1029-1042.

5. Yu, W., Sang, Y., Wang, T., Liu, W., \& Wang, X. (2020). Electrochemical immunosensor based on carboxylated single-walled carbon nanotube-chitosan functional layer for the detection of cephalexin. Food Science \& Nutrition, 8(2), 1001-1011.

6. Chullasat, K., Kanatharana, P., \& Bunkoed, O. (2019). Nanocomposite optosensor of dual quantum dot fluorescence probes for simultaneous detection of cephalexin and ceftriaxone. Sensors and Actuators B: Chemical, 281, 689-697.

7. Blazheyevskiy, M. Y., \& Serdiukova, Y. Y. (2017). Comparison of three independent methods of Cephalexin determination by means of potassium caroate. Ars Pharm. 58(2), 59-65.

8. H.Al-kahdimy, A. S. and Ahmed, M. A. (2016). Flame Atomic Emission and Colorimetric Methods for the Determination of Cephalexin Monohydrate in Pharmaceutical Preparations. Baghdad Science Journal, 13, 2488-480 .

9. Mohammed, M. A., Mezaal, E.N. and Sadiq, K.A. (2016). Simultaneous determination of cephalexin and cefixime by first and second derivative ultraviolet spectrophotometry. Journal of the College of Basic Education, 22(93), 89-100.

10. Balooei, M., Raoof, J. B., Chekin, F., \& Ojani, R. (2017). Cephalexin electrochemical sensors based on glassy carbon modified with 3-mercapto propyltri methoxysilane functionalized multi-walled carbon nanotubes. Anal. Bioanal. Electrochem, 9, 929-939.

11. Mshref, M. F., Ghonemy, H.M and Ali, A.H. (2017). Determination of beta-lactamase inactivation of cephalexin by validated RP-HPLC method. World Journal of Applied Chemistry, 2(4), 120.

12. Abbas, R. F. (2020). Different Mathematical Spectrophotometric Methods for Determination of Ampyrone in Presence of Its Acid Degradation Product. Al-Mustansiriyah Journal of Science, 31(3), 72-77.

13. Abbas, R. F., Mahdi, N. I., Waheb, A. A., Aliwi A. G. and Falih, M. S. (2018). Fourth Derivative and Compensated Area under the Curve Spectrophotometric Methods Used for Analysis Meloxicam in the Local Market Tablet. Al-Mustansiriyah Journal of Science, 29(3 ICSSSA 2018 Conference Issue), 70-76. 


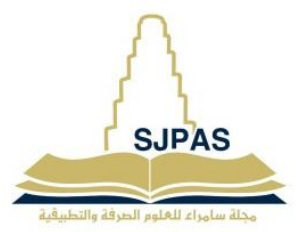

طريقتين طيفيتين بسيطتين لتقدير السيفالكسين بصورتيه النقية والصيدلانية

نداء ابراهيم مهـدي

قسم الكيمياء، كيلة العلوم، الجامعة المستتصرية (nadamahde@uomustansiriyah.edu.iq)

\begin{tabular}{|c|c|}
\hline 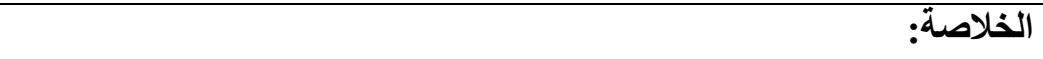 & 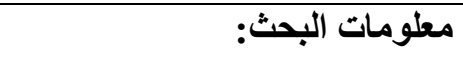 \\
\hline في هذه الدراسة، تم تقدير السيفالكسين بطريقتين طيفيتين بسيطتين دون الحاجة & 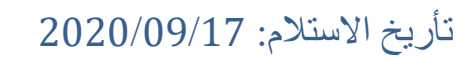 \\
\hline إلى الاستخلاص لتقدير السيفالكسين بصورتيه النقية والمستحضرات الدوائية. & تأريخ القبــــ: 2021/01/04 \\
\hline كلا الطريقتان تعتمدان على طيف الاشعة فوق البنفسجية، حيث اظهرت طريقة & \\
\hline المرتبة الصفرية اعلى امتصاص عند الطول الموجي 263 نانومتر ، بينما نم في & الكلمات المفتاحية: الكية: \\
\hline الطريقة الثانية الاعتماد على المساحة تحت المنحني ضمن المدى (260-266 & سيفالكسبن، المساحة تحت الدنحني، \\
\hline 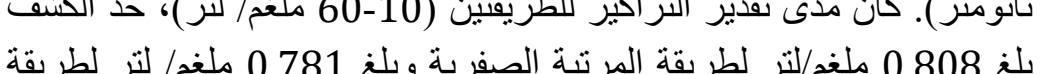 & \\
\hline 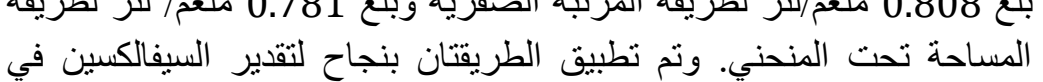 & \\
\hline المستحضر ات الصيدلانية. & \\
\hline
\end{tabular}

